Discussion Paper No. 07-018

Motives for Innovation Co-operation Evidence from the Canadian Survey of Innovation

Tobias Schmidt

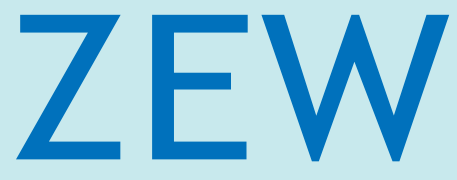

Zentrum für Europäische Wirtschaftsforschung $\mathrm{GmbH}$ Centre for European Economic Research 
Discussion Paper No. 07-018

\section{Motives for Innovation Co-operation - Evidence from the Canadian Survey of Innovation}

Tobias Schmidt

Download this ZEW Discussion Paper from our ftp server:

ftp://ftp.zew.de/pub/zew-docs/dp/dp07018.pdf

Die Discussion Papers dienen einer möglichst schnellen Verbreitung von neueren Forschungsarbeiten des ZEW. Die Beiträge liegen in alleiniger Verantwortung der Autoren und stellen nicht notwendigerweise die Meinung des ZEW dar.

Discussion Papers are intended to make results of ZEW research promptly available to other economists in order to encourage discussion and suggestions for revisions. The authors are solely responsible for the contents which do not necessarily represent the opinion of the ZEW. 


\title{
Motives for Innovation Co-operation - Evidence from the Canadian Survey of Innovation
}

\author{
Tobias Schmidt ${ }^{1}$
}

\begin{abstract}
In this paper we analyse the decision of firms in the Canadian manufacturing sector to co-operate on innovation projects. Our focus is on the motives behind this decision and the firm characteristics, both general and with respect to innovation activities, which influence the motives for innovation co-operation. Using data from the Canadian Survey of Innovation 2005 we find that the factors influencing the decision to co-operate in order to access external knowledge are very similar to those influencing cost-sharing motives. We also show that public funding leads firms to cooperate in order to access external knowledge and R\&D.
\end{abstract}

Keywords: Innovation Co-operation, Motives for Co-operation, Canadian Survey of Innovation

JEL Codes: O31, O32, L22

DISCLAIMER: The research and analysis are based on data from Statistics Canada and the opinions expressed do not represent the view of Statistics Canada.

Acknowledgements: I would like to thank Fred Gault and his team at the SIEID division of Statistics Canada for not only making my visit at Statistics Canada in Ottawa possible but also for making it an enjoyable one. I am also indebted to the ZEW for financing my study visit in Ottawa. Finally, I would like to thank Susan Schaan, Frances Anderson, Guy Sabourin, Raymond Leung, Bettina Peters, Wolfgang Sofka and Christian Rammer for providing valuable comments and assistance.

1 Center for European Economic Research (ZEW), Department of Industrial Economics and International Management, P.O. Box 1034 43, D-68034 Mannheim, Germany, schmidt@zew.de 


\section{Non-technical summary}

"Yahoo!, eBay link up for online showdown" (The Gazette, 2006) and "Ebay talks to Microsoft, Yahoo about foe" (Wall Street Journal Europe, 2006) were the headlines that came along with the discussions about a possible co-operation between some of the major players in the internet and online search business. This is just one example of how important co-operation between firms has become in recent years. Cooperations between firms and between firms and public research institutes have not been confined to marketing or sales alliances but have increasingly been targeted at $R \& D$ and innovation activities. Shorter product-life cycles, more complex technologies and increased possibilities for sharing knowledge and research results have all lead firms to look for partners for their R\&D and innovation activities.

Initiated by this increase in inter-firm co-operation, a large body of empirical and theoretical literature on firms' motives to co-operate in R\&D and innovation activities has developed. The motives firms have to conduct joint innovation activities are the starting point for this paper. We analyse how firms' characteristics and measures of their innovation activities influence the underlying motives of their decision to cooperate in innovation. We use data from Statistic Canada's Survey of Innovation in 2005 to look at firm characteristics that lead firms to co-operate for one or the other reason. The survey includes a direct question on motives for innovation co-operation related to the development and the commercialization of product and process innovations.

Our findings indicate that firms which co-operate in order to share the costs of developing innovative products and processes and those that get involved in innovation co-operation in order to access external knowledge are quite similar. They have R\&D activities that are relatively more oriented towards basic than applied research, are large and more often belong to industries related to science. They also assign a high importance to strategic and formal protection methods. To put it simply, they are more research oriented than other firms.

The firms that co-operate in order to scale up production and to commercialize innovations, respectively, are harder to describe. Both groups have in common that the innovation intensity has a positive effect after a certain threshold is reached, while the share of employees with university degrees and the share of employees involved in $R \& D$ activities do not. We find some evidence that public funding increases the flow of knowledge within the national system of innovation. Innovators are more likely to co-operate in order to get access to external $\mathrm{R} \& \mathrm{D}$ and expertise if they receive public funding than if they do not receive public funding. 


\section{Introduction}

"Yahoo!, eBay link up for online showdown" (The Gazette, 2006) and "Ebay talks to Microsoft, Yahoo about foe" (Wall Street Journal Europe, 2006) were the headlines that came along with the discussions about a possible co-operation between some of the major players or rather competitors in the internet and online search business. This is just one example of how important co-operation between firms has become in recent years. Co-operations between firms and between firms and public research institutes have not been confined to marketing or sales alliances but have increasingly been targeted at R\&D and innovation activities. Shorter product-life cycles, more complex technologies and increased possibilities to share knowledge and research results have all lead firms to seek partners for their $R \& D$ and innovation activities. This upward trend in $R \& D$ partnerships has been documented among others by Hagedoorn (2002) and the OECD (OECD, 1986).

Initiated by this increase in inter-firm co-operation, a large body of empirical and theoretical literature on firms' motives to co-operate on R\&D and innovation activities developed. A number of co-operation motives have been identified, like gaining access to (foreign) markets, sharing of costs and risk, the joint development of product and process innovations or access to complementary knowledge, to name a few. In recent years the role of knowledge in the innovation co-operation process has been extensively analysed empirically using data from the Community Innovation Surveys. It has been shown that gaining access to knowledge held by institutions and firms outside a firm's own boundary and controlling knowledge outflows to the public domain ("internalizing spillovers") is one of the main reasons why firms and institutions co-operate on innovation activities of various kinds.

The motives firms have to conduct joined innovation activities, is the starting point for this paper. Statistic Canada's Survey of Innovation in 2005 includes a direct question on the co-operation motives of firms ${ }^{1}$. The survey includes both, motives related to the development and motives related to the commercialization of product and process innovations. Thus - contrary to other studies - we will not have to construct proxy measures of motives but have direct evidence on firms' co-operation motives. This allows us to look at firm characteristics, ranging from their innovation activities to the industry they belong to, that lead firms to cooperate for one or the other reason, instead of analysing the co-operation decision in general and using proxies for the motives. This analysis will serve as the basis for generating a profile of firms that co-operate for a given reason on their

\footnotetext{
${ }^{1}$ We will use the term "firm" throughout this paper even though the unit of observations for the Canadian Survey of Innovation is the establishment and the term used in the questionnaire is "plant". For more details on the methodology of the survey see the website of Statistics Canada: www.statcan.ca/cgibin/imdb/p2SV.pl?Function=getSurvey \&SDDS=4218\&lang=en $\& d b=I M D B \& d b g=f \& a d m=8 \& d i s=2$
} 
innovation activities and may help policy makers to target the right group of firms if they e.g. see the need for more innovation co-operation on commercialization. In that respect our study is closely related to the empirical work that deals with the characteristics of firms co-operating with specific partners (see e.g. Mohnen and Hoareau, 2003).

Our study's set-up is similar to the studies that differentiate between different co-operation partners. Its focus is however not on investigating the motives for cooperating with a certain partner, but rather to develop a typology of firms that co-operate for a given reason.

The following section will review the literature on motives for innovation cooperation with a focus on the more recent empirical findings. In section 3 we will describe the data we use and the set-up of the empirical model. Section 4 presents the results of our econometric analysis. Finally, section 5 will conclude and provide some ideas for future research.

\section{Literature Review}

The literature review has two main parts. First, we will review some of the empirical literature on the motives for innovation and R\&D co-operation. This section is meant to provide some background on the motives included in the questionnaire, which we will use to construct our dependent variables. The second part of the review will focus on papers looking at the characteristics of firms that collaborate with external partners on innovation activities. The distinction between the two sections is not always clear cut, as most authors from the second group interpret their findings on firm characteristics and innovation behaviour as motives for innovation co-operation.

\section{Motives for Innovation Co-operation ${ }^{2}$}

Initiated by the increase in inter-firm innovation co-operation, a large body of literature on firms' motives for co-operating on R\&D and innovation activities emerged (for an overview of the earlier empirical papers see Hagedoorn, 1993). This new strand of literature stresses the role of R\&D co-operation in transferring knowledge between actors in an economy. The link between knowledge spillovers and R\&D co-operation is now very well established in both the empirical and theoretical literature on R\&D co-operation. Many papers have shown that generating, internalizing and preventing knowledge spillovers

\footnotetext{
${ }^{2}$ We will use the terms „R\&D co-operation“ and ,innovation co-operation” interchangeably. The former term is used in most empirical studies on the subject although the data used covers co-operation on innovation activities other than R\&D activities as well.
} 
between firms and firms and public institutions are an important motive for cooperation (e.g. Cassiman and Veugelers, 2002; Kaiser, 2002; Belderbos et al., 2004; D'Aspremont and Jacquemin, 1988; Kamien et al., 1992; De Bondt and Veugelers, 1991).

Another strand of literature dealing with this topic is the resource based view (RBV) of the firm (Wernerfelt, 1984; Barney, 1991). Starting points for the arguments brought forward by the RBV on R\&D co-operation are the papers by Richardson (1972); Barney (1991) and Teece (1986). They argue that it may be necessary for firms to access complementary external resources in order to be able to exploit their own internally held resources better. This is the case in particular if firms' own resources are immobile and can not be exchanged through regular market transactions. Firms which want to profit from their immobile resources by combining it with external knowledge have thus to cooperate with the firm possessing these complementary resources (Hagedoorn et al., 2000; Tsang, 2000). Mowery and his co-authors summarize their discussion of the research based view and partner choice for co-operation by stating "the resource based-view argues that a key motive for the formation of alliances is the desire of participants to acquire capabilities from an external source." (Mowery et al., 1998: 511). Empirical evidence for the RBV's arguments has been provided by Cantner and Meder (2006). They show that firms' incentives to cooperate on R\&D are higher if the potential partner has complimentary (and highvalue) knowledge. For co-operation with suppliers and clients Miotti and Sachwald (2003) find: the main motives are "to pool complimentary resources and access more market information" (Miotti and Sachwald, 2003: 1496). Similarly, some authors of the RBV argue that R\&D co-operation between firms are undertaken in order to learn from the partners in the co-operative agreement (Caloghirou et al., 2003; Tsang, 2000). Alliances - a special form of co-operation - are also seen as a method to transfer tacit knowledge (Polanyi, 1967) across firm boundaries (Kogut, 1988).

Other motives beyond knowledge transfer and access to knowledge have been discussed in the empirical and theoretical literature ${ }^{3}$. Hagedoorn (1993) compiled the following list of strategic motives based on a large literature review of studies on the determinants of R\&D co-operation (mainly in large firms) before 1993:

\footnotetext{
${ }^{3}$ The most fundamental of all co-operation motives is of course to generate (long- and/or short-term) profits from innovation co-operation. That R\&D co-operation can lead to an increase in the innovative (and economic success) of firms has been empirically confirmed by Cincera et al. (2003) and Aschhoff and Schmidt (2006) to name a few.
} 
Table 1 An Overview of Motives for (Strategic) Inter-Firm Technology Cooperation

\begin{tabular}{ll}
\hline I & Motives related to basic and applied research and some general \\
characteristics of technological development: \\
- Increased complexity and inter-sectoral nature of new technologies, cross- \\
fertilization of scientific disciplines and fields of technology, monitoring of \\
evolution of technologies, technological synergies, access to scientific \\
knowledge or to complementary technology \\
- $\quad$ Reduction, minimizing and sharing of uncertainty in R\&D \\
- $\quad$ Reduction and sharing of costs of R\&D \\
II $\quad$ Motives related to concrete innovation processes \\
- $\quad$ Capturing of partner's tacit knowledge of technology, technology transfer, \\
- $\quad$ Sechnological leapfrogging \\
III $\quad$ Mortening of product life cycle, reducing the period between innovation \\
- $\quad$ Monitives related to market access and search for opportunities \\
- $\quad$ Internationalization, globalization and entry to foreign markets \\
- $\quad$ New products and markets, market entry, expansion of product range \\
\hline
\end{tabular}

Source: Hagedoorn, 1993: 373 (shortened).

Sakakibara (1997) supports the view that the sharing of costs and risks ${ }^{4}$ is a basic motive for co-operation. She argues that firms try to reduce their own project costs by cooperating with external partners. Since expensive projects usually also bear a high risk for the firms undertaking them cost and risk sharing as a motive for co-operation are related to each other ${ }^{5}$. Miotti and Sachwald (2003) find support for the last group of motives in Hagedoorn's list. They show that firms co-operate in R\&D in order to be able to access new (foreign) markets. Bayona et al. (2001) in a study of over 1,600 Spanish firms, does not find a significant effect of market access motives on the likelihood for R\&D co-operation, though. They support Sakakibara (1997) and find that cost-sharing and uncertainty are motivations for R\&D co-operation among firms.

Veugelers and Cassiman (2005), Belderbos et al. (2004), Kaiser and Licht (1998), Dachs et al. (2004), Bönte and Keilbach (2005), Fontana et al. (2005) and many other researchers investigate motives for different types of $R \& D$ partnerships, like co-operation with vertically related suppliers and customers, horizontally related competitors or public research institutions. All these studies agree that the importance of a certain motive differs for R\&D co-operation with

\footnotetext{
${ }^{4}$ See also Banerjee and Lin, 2001.

${ }^{5}$ Contrastingly, Veugelers and Cassiman (2005) and Schmidt (2005b) show that cost and risk have opposite effects on the likelihood of firms to co-operate: While risk-sharing has a negative effect, cost-sharing has a positive effect.
} 
different partners. This does not mean, however, that they agree on all the motives for the different types of R\&D co-operation.

To summarize this first part of the literature review, the main motives for innovation co-operation seem to be access to (complementary) knowledge, the sharing of cost and risk for developing innovations and getting access to new markets.

\section{Factors Influencing Firms’ Innovation Co-operation Decisions}

Miotti and Sachwald (2003) use data from the French CIS II innovation survey to analyse the impact of various factors on a firm's R\&D co-operation decision. The factors they look at range from the size of the firm and its industry, to the market share, public funding, obstacles to innovation and permanent R\&D. One finding of their study is that "a strong research orientation substantially increases their [firms'] propensity to co-operate" (Miotti and Sachwald, 2003: 1490). Bayona et al. (2001) support Miotti and Sachwald (2003) on the effect of R\&D activities and show that in-house R\&D activities and belonging to a highly technology-intensive industry increase a firm's propensity to collaborate on innovation activities. Bayona et al. (2001) interpret their finding as a positive influence of absorptive capacity (Cohen and Levinthal, 1989, 1990) on the probability of co-operating on R\&D. Dachs et al. (2004) and Belderbos et al. (2004) use the innovation-intensity, i.e. the share of R\&D expenditure over total turnover, to represent absorptive capacity in their models6 and also find a positive influence on the probability to co-operate on innovation activities. In addition to representing a firm's ability to source external knowledge these indicators can also been seen as a measure of the need of firms for external knowledge (Fritsch and Lukas, 2001). Other studies that find a positive link between own R\&D and innovation co-operation include Fritsch and Lukas (2001), Bönte and Keilbach (2005) and Fontana et al. (2005). Cassiman and Veugelers (2002) (2-step results) and Rocha (1999) do not find a significant influence, however.

Absorptive capacity is closely related to knowledge, so is the importance of legal and strategic protection methods for inventions, which are supposed to protect knowledge from flowing out (see Cassiman and Veugelers, 2002; Bönte and Keilbach, 2005). Dachs et al. (2004) find different effects for the usage of strategic and formal methods of protection for inventions and innovations between Austria and Finland. In Finland the likelihood to co-operate on innovation activities increases significantly, if the firm uses strategic and formal protection methods, in Austria it does not. Cassiman and Veugelers (2002) have discussed this topic under the label of "appropriability". They find that the higher

\footnotetext{
${ }^{6}$ See Schmidt (2005a) for a review of empirical measures of absorptive capacity.
} 
the importance of strategic protection methods for a Belgium firm, the more likely it is to co-operate.

Dachs et al., 2004 investigate the role of the novelty of a product innovation in a firm's co-operation decision and find that firms which develop and introduce products new to their market ("market novelties") are more likely to co-operate with external partners than others. Furthermore Capron and Cincera, 2004 argue that the development of more novel products requires more fundamental research than the development of less novel products. If the firm does not have the necessary capacity to conduct fundamental research in-house it is very likely to co-operate with external partners (in particular universities) to access their knowledge.

Abramovsky et al. (2005) find that the recipients of public support are more likely to co-operate than firms without public support in all four European countries they look at, i.e. France, Germany, the UK and Spain. Negassi (2004) also shows that a firm is more likely to co-operate on innovation activities if it receives public support. Busom and Fernandez-Ribas (2004) find a positive effect of participation in national R\&D programs on the likelihood to cooperate using data from the Spanish innovation survey of 1999. Dachs et al. (2004) present one of the few studies on European data that does not find a positive impact of public support on the probability of co-operating on innovation activities in general. They do find a significant positive impact for Finland, but not for Austria. However, in Austria public funding has a positive and significant impact on co-operating with universities and public research institutions and customers, which can be attributed to the fact that many public funding programs are directed to foster co-operation between public institutions and private firms.

As far as some more general firm characteristics are concerned, Miotti and Sachwald (2003) show that larger firms, firms from high-tech and medium-hightech sector and firms belonging to a group are more likely to co-operate ${ }^{7}$. The former finding, i.e. that firm size has a positive effect on the likelihood of cooperating in $\mathrm{R} \& \mathrm{D}$, is supported by many other empirical studies (e.g. Röller et al., 1997, Link and Bauer, 1987 and Cassiman and Veugelers, 2002 (inverse ushaped)). Bönte and Keilbach (2005) confirm this finding for informal collaboration. They show that larger firms are more likely to collaborate with customers and suppliers both formally and informally than small firms. There are several reasons why size has a positive influence on the probability to co-operate: Dachs et al. (2004) for example argue in their literature review that large firms are more likely to have the resources to actively look for partners for their innovation projects and are thus more likely to co-operate than small firms. Large firms also have a higher incentive to cooperate with external partners simply

\footnotetext{
${ }^{7}$ Belonging to a group has been shown to have a negative effect on co-operating with horizontally related firms by Belderbos et al. (2004). Mohnen and Hoareau (2003) show that belonging to a group reduces the likelihood of co-operating with public research institutions. The likelihood to co-operate in general increases, however, if the firm belongs to a group.
} 
because they focus on their core business and have to acquire complementary knowledge and services from outside their own boundaries (Gerybadze, 2004). Fritsch and Lukas (2001) present another argument for the influence of size. They argue that if "there exists a given probability for co-operation per unit of economic activity" (Fritsch and Lukas, 2001: 300) then large firms should be more likely to conduct co-operative R\&D than small firms with less economic activity. The argument goes like this, the more economic activity a firm has the more likely it is to have innovative projects and the more innovative projects it has the more likely it becomes to co-operate on innovation. Bayona et al. (2001) is no exception to the rule. In a study of over 1,600 Spanish R\&D performing firms, they find that larger firms are more likely to co-operate than smaller firms.

As far as the industry is concerned, Tether (2002) finds that low technology firms in services are less likely to cooperate than firms from other industry groups. Similarly, Dodgson (1994) shows that high-tech industries are more likely to co-operate on R\&D activities. Descriptive statistics from the CIS for the member states of the European Union also show significant differences in the share of firms involved in R\&D co-operation in each industry (European Commission, 2004). These results can partially be attributed to different R\&D intensities and funding schemes in different industries. Bönte and Keilbach (2005) find that firms in more dynamic industries are more likely to cooperate both formally and informally.

Another general characteristic of firms is their export orientation. Dachs et al. (2004) argue that the export orientation of firms matters for their R\&D cooperation decision. They do not find empirical evidence for this hypothesis, however. Similarly, Busom and Fernandez-Ribas (2004) do not find empirical evidence for a link between export intensity, measured as the share of exports over total sales, and the likelihood of cooperating on R\&D activities. They reject their hypothesis that exporting firms have access to a larger variety and number of potential co-operation partners (e.g. international firms) than non-exporting firms and are thus more likely to cooperate.

In summary, the existing literature shows that several different innovation and R\&D activities of firms have an influence on the probability to co-operate. Besides these factors, general firm characteristics and framework conditions, like their size and industry do also play a role in their innovation co-operation decision.

\section{Analytical Framework}

The analytical approach of most of the recent studies on innovation cooperation (e.g. Belderbos et al., 2004; Abramovsky et al., 2005; Miotti and Sachwald, 2003; Veugelers and Cassiman, 2005; Dachs et al., 2004; Bönte and Keilbach, 2005) - all using data from the Community Innovation Surveys (CIS) - 
is very similar: They construct measures of firms' co-operative behaviour, knowledge spillovers, and other factors influencing the innovation co-operation decision, from questions on sources of information for innovation activities or obstacles to innovation activities and other questions. Their approach is to determine the effect of these proxy measures on the likelihood that a firm cooperates by regressing them on a dummy variable which takes the value one if the firm co-operates on innovation activities during a given reference period. The independent variables which are significant are then interpreted as a motive for R\&D co-operation. As with all proxy measures the argument is that the constructed measure is closely related to the actual underlying motive.

Our approach is different: The Canadian Survey of Innovation 2005 contains a direct question on the motives for innovation co-operation, which covers most of the motives listed in the literature review above. They range from the sharing of costs for innovation activities, gaining access to critical expertise to accessing new markets. This data allows us to address how firms' innovation behaviour and characteristics influence their R\&D co-operation motives. We follow the existing literature in analysing different types of innovation co-operation, but instead of distinguishing innovation co-operations by the partners involved (e.g. Belderbos et al., 2004) or the intensity of the relationship (e.g. Bönte and Keilbach, 2005), we distinguish them by their underlying motive. The proxy measures used to represent the motives in the existing literature can thus no longer be interpreted as the motives for R\&D co-operation but are rather indicators of the innovation behaviour of firms, public support for $R \& D$ and more general firm characteristics. We will thus be able to identify the relationship between these indicators (part 2 of the literature review) and some of the motives for cooperation (part 1 of the literature review).

An example of a study similar to ours is the one by Hagedoorn (1993). He analyses data from the MERIT-CATI database on published innovation and R\&D co-operations between firms, which contains direct information on the motives underlying the co-operative agreements. Using descriptive statistics he shows that the motives for $\mathrm{R} \& \mathrm{D}$ co-operation differ significantly across industries. Beyond this study the literature provides (to our knowledge) little evidence on which factors influence which type of R\&D co-operation motives. To structure our analysis we will look at the two areas identified in the literature review for potential determinants: firms' innovation behaviour and general firm characteristics. Public support for R\&D is without a doubt an input for the innovation activities of firms. We will nonetheless treat it as separate category, given that it represents the factor that can most easily and directly be influenced by policy makers.

The actual measures used to represent these three groups and their expected effects on the motives will be described in the following section. The choice of variables for each of the three groups is mainly based on those variables used in the literature. To some degree our study is still exploratory, however, given the 
scarcity of literature on our specific topic, i.e. factors that influence the choice of co-operating for a specific motive.

The following figure summarizes our analytical framework:

Figure 1 Analytical Framework for the Empirical Part of the Paper

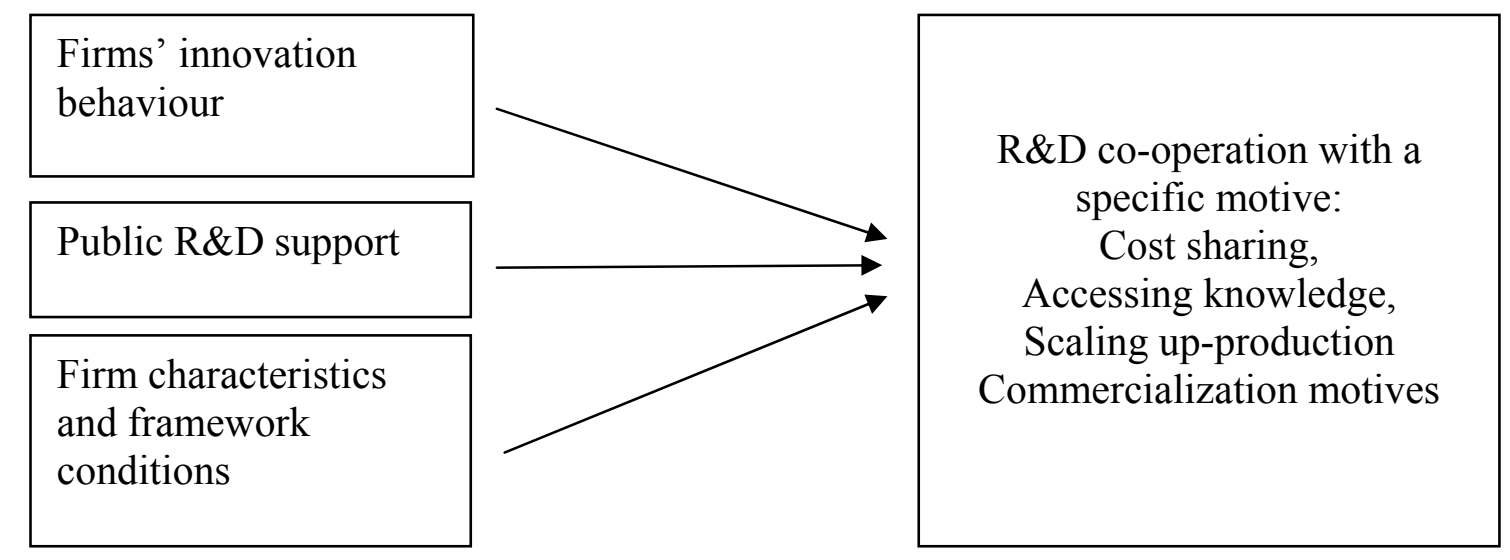

\section{Data and Empirical Model}

In order to investigate the factors which influence the choice of co-operation motives, we use the 2005 Survey of Innovation of the Science, Innovation and Electronic Information Division (SIEID) at Statistics Canada. The mandatory survey was undertaken between September 2005 and March 2006 and covers firms with 20 or more employees and at least $\$ 250,000$ in revenues in the Canadian manufacturing sector (NAICS 31-33) ${ }^{8}$. A stratified random sample ${ }^{9}$ of 8,902 firms was selected. The Chief Executive Officer (CEO) or senior managers of the firms chosen were sent a mail questionnaire. This questionnaire contains questions on firms' innovation behaviour and their characteristics for the reference period 2002 to 2004. The definitions of the concepts used in the questionnaire are based on the so called "Oslo Manual" (OECD and Eurostat, 1997), the international handbook for innovation surveys. The data was produced respecting the quality standards of Statistics Canada, namely, data relevance, accuracy, timeliness, accessibility, interpretability and coherence. ${ }^{10}$

\footnotetext{
${ }^{8}$ The survey also covered logging (NAICS 1133), which is excluded from our analysis.

${ }^{9}$ The stratification is based on the industry, region (province or groups of provinces/territories in the case of the western provinces and the territories) and establishment size.

${ }^{10}$ Additional Information on the survey and the questionnaire used can be found on the Statistics Canada Website at the following address: http://www.statcan.ca/english/sdds/4218.htm
} 


\section{Construction of the Dependent Variables}

Statistic Canada's Survey of Innovation 2005 contains a number of questions on firms' innovation co-operation behaviour, like the type of partner and its location and the motives for innovation co-operation ${ }^{11}$. The latter will be the main focus of our study. In the survey firms are asked to indicate their motives for innovation co-operation between 2002 and $2004^{12}$ in two broad categories, development of innovation and commercialization of innovation. The first category covers sharing of costs, accessing $\mathrm{R} \& \mathrm{D}$, accessing critical expertise, prototype development and scaling up production processes. The second group of motives contains two commercialization motives, access to new markets and access to new distribution channels. In the "Innovation Analysis Bulletin" of Statistics Canada Michael Bordt wrote that the "commercialization of innovation focuses on the contribution to the economy of new and significantly improved products" (Michael Bordt, 2005: 3). This motive does not exclusively apply to product innovators, however. We find a number of firms that have only introduced process innovations between 2002 and 2004, but co-operated for commercialization reasons with external partners. A reason for this finding may be that they are commercializing older innovations or are already preparing for the commercialization of upcoming products. Given the evidence that process innovators also co-operate for commercialization reasons, we do not restrict our sample to product innovators, but analyse the factors influencing the decision to collaborate with external partners to commercialize innovations for both product and process innovators. The dependent variable representing this motive is labelled $m \_$com.

In addition to commercialization motives, we will also look at the development of innovations as a motive for collaboration. Since almost all co-operating firms in our sample indicated that at least one of the items listed under "development of innovation" was an important motive for innovation co-operation, we split-up the development motives into three subgroups: sharing of costs for developing innovations ( $\left.m \_c o s t\right)$, accessing external knowledge ( $\left.m \_k n o w l\right)$ comprising of

${ }^{11}$ The Canadian Survey of Innovation 2005 is one of the few surveys which contains a direct question on the motives for innovation co-operation. The other surveys we are aware of are the 2002 Swiss Innovation Survey and the 2003 New Zealand Innovation Survey. The MERIT-CATI database also contains direct evidence on the motives for co-operation (see Hagedoorn, 1993), it covers only cooperative agreements published in a wide range of technological and scientific journals.

The exact question was phrased as follows: "Please check which of the following reasons were important in determining the involvement of your business unit in co-operative arrangements to develop or commercialize new or significantly improved products (goods or services) and/or processes." Firms had to answer this question if they had answered "yes" to the following question "During the three years, 2002 to 2004, did your plant co-operate on any of your innovation activities with other firms or institutions?" which was supplemented by a definition of innovation cooperation: "Innovation co-operation is active participation with other firms or organizations on innovation activities. Exclude pure contracting out of work where there is no active co-operation." (Statistics Canada, 2005). 
accessing R\&D and accessing critical expertise and the third group scaling up production processes $\left(m \_s c a l e\right)^{13}$. All the variables representing the motives in the empirical model are dummy variables, which take the value one if the firm has indicated that the given motive was important for co-operating on innovation activities between 2002 and 2004. ${ }^{14}$ Since we are interested in co-operation with external partners, we excluded six observations. These were firms which are only co-operating with other firms within their firm ${ }^{15}$.

Descriptive Statistics show that the most important motive for co-operation in all industry groups is to access external knowledge (critical expertise and R\&D done by other firms). Over $81 \%$ of all firms that co-operated between 2002 and 2004 did it for this reason. Commercialization motives, sharing cost-risk and scaling up production processes were less important. These other motives are deemed important by less than $50 \%$ of the innovating firms. In some industries however cost-sharing is a motive relevant to more than $50 \%$ of cooperating firms with the exception of cost-sharing (science: $53.7 \%$ and specialized industry: $64.2 \%$ ). Scaling up production is mentioned by $53.3 \%$ of co-operating firms in scale-intensive industries as an important motive for R\&D co-operation.

Table 2 Percentage of Firms that Co-operated on Innovation Activities for a Given Motive between 2002 and 2004, by Industry Groups ${ }^{16}$

\begin{tabular}{lcccc}
\hline $\begin{array}{l}\text { Industry } \\
\text { Groups }\end{array}$ & $\begin{array}{c}\text { Sharing the } \\
\text { cost of } \\
\text { developing } \\
\text { innovations }\end{array}$ & $\begin{array}{c}\text { Accessing research } \\
\text { and development } \\
\text { (R\&D), accessing } \\
\text { critical expertise }\end{array}$ & $\begin{array}{c}\text { Scaling up } \\
\text { Production } \\
\text { Processes }\end{array}$ & $\begin{array}{c}\text { Accessing new } \\
\text { markets, } \\
\text { accessing new } \\
\text { distribution } \\
\text { channels }\end{array}$ \\
\hline $\begin{array}{l}\text { Resource } \\
\text { intensive }\end{array}$ & $46.1 \%$ & $83.4 \%$ & $47.4 \%$ & $46.4 \%$ \\
\hline $\begin{array}{l}\text { Labour } \\
\text { intensive }\end{array}$ & $45.4 \%$ & $74.5 \%$ & $35.0 \%$ & $44.1 \%$ \\
\hline $\begin{array}{l}\text { Scale } \\
\text { intensive }\end{array}$ & $49.3 \%$ & $78.3 \%$ & $53.3 \%$ & $47.4 \%$ \\
\hline Science & $53.7 \%$ & $87.9 \%$ & $49.3 \%$ & $44.9 \%$ \\
\hline Specialized & $64.2 \%$ & $90.1 \%$ & $22.0 \%$ & $49.1 \%$ \\
\hline Total & $49.8 \%$ & $81.4 \%$ & $42.5 \%$ & $45.9 \%$ \\
\hline \hline
\end{tabular}

Source: Statistics Canada - Survey of Innovation 2005.

${ }^{13}$ Except for the last motive ( $\left.m \_s c a l e\right)$, these motives can be found under different headings in Hagedoorn's table presented on page 4 of this paper.

${ }^{14}$ A more detailed description of these and the other variables included in our empirical model is given in Table 4 in the appendix.

${ }^{15}$ Note, even after dropping these observations we are not able to fully distinguish between motives for collaboration with external partners and collaboration with internal partners because some firms have collaborated with both types of partners between 2002 and 2004 and not just external ones.

${ }^{16}$ See Table 5 in the appendix for details on the construction of the industry variables. 


\section{Construction of the Independent Variables}

The three different groups of factors that potentially influence the motives firms have for co-operating with external partners are represented in our empirical model by the following set of independent variables:

Firms' innovation behaviour is included in the model, by adding dummy variables for the degree of novelty ${ }^{17}$ of their product and process innovations (pdnov and pznov), innovation activities related to the market introduction of innovations (act_market), innovation activities related to post-introduction commercialization of products (act_com) and internal R\&D activities (act_rdintp). In addition to these qualitative measures we also included the innovation intensity, measured as the percentage of a firm's total sales that were devoted to innovation activities in 2004 (inno_int and inno_int2), the share of employees involved in R\&D activities in 2004 ( $r d p)$, the share of employees with at least a university degree (uni), and an index of the "basicness" of the firms innovation approach (basic). We try to capture the "basicness" by calculating the ratio between the importance of institutional source of information for innovations and the importance of market sources, a method similar to the one used by Cassiman and Veugelers (2002) and Abramovsky et al. (2005). To capture some of the strategic aspect of the innovation activities of firms we also include a measure for the importance firms assign to strategic (prot_strat) and formal protection (prot_form) methods for innovations and inventions, respectively. These two measures indicate how concerned firms are about protecting their knowledge from being used by others (see literature review) and how important innovations are for the firm. Besides, in order to be able to protect an invention with patent or trademark protection methods it has to fulfill the novelty criteria ("inventive step") laid down in the patent and trademark laws. The importance of formal protection methods can thus also be seen as an additional measure of the novelty of an invention or innovation. The importance of strategic and formal protection methods can also be interpreted as an indication of the framework conditions and the technological environment under which firms co-operate, because the importance of certain protection methods is certainly not independent of the technology of a firm's industry and the behaviour of other firms.

Our choice of variables to represent the innovation behaviour of firms allows us to look at inputs to the innovation process (inno_int, rdp, uni, act_rdintp), the innovation strategy (basic, prot_strat, prot_form $)^{18}$, outputs of innovation activities ( $\left.p d \_n o v, p z \_n o v\right)$ and activities related to the introduction and commercialization of the output (act_com, act_market).

\footnotetext{
${ }^{17}$ Products and processes can be either new to the firm, new to the province/territory, new to Canada, new to North America or new to the world.

${ }^{18}$ Some of the other variables could also be considered innovation strategy like the novelty of products and processes introduced.
} 
A second group of factors we include in our empirical model are firm characteristics and framework conditions for innovation activities. They are discussed under one group since some factors can be attributed to both subgroups, like the industry a firm is operating in (ress-int, labor-int, scale-int, science, specialized $)^{19}$. The industry is certainly a feature that describes the firm, but it also sets the framework conditions for its activities. Similarly, the obstacles a firm faces with respect to its innovation activities are shaped by its environment but also by its own set-up and capabilities. We include the relative importance of obstacles related to the development of innovations compared to obstacles to the commercialization of innovation (obst_rel) in our empirical model. Besides the industry of the firm and the importance of obstacles, this second group of independent variables also included the export share of the firm, i.e. the percentage of total revenue that came from sales in markets outside of Canada (exp_share), a measure of the concentration on the demand-side (demand), a dummy variable indicating if the firm is part of a group of firms or an independent firm by itself (group) and a firm's size, measured as the number of employees (Inemp and Inemp2).

The final group of independent variables is actually not a group, since it comprises only a dummy variable, which is one if the firm has received any public funding or support for its innovation activities (public).

Most of the variables we construct are only available for firms that innovated between 2002 and 2004. Limiting our sample to firms that innovated during this three year period leaves us with 4021 observations which represent 10860 firms of the total population.

\section{Expected Effects on Different Co-operation Motives}

The expected effects of these factors on the choice of motives for innovation co-operation are the following:

We would expect the novelty of a product or process innovation to have a positive effect on the likelihood that firms co-operate with external partners in order to acquire knowledge, because the development of more novel products usually involves more risk than modifying existing products and also requires knowledge from different domains, which is not available from sources within the firm.

The effect of the three innovation activities: innovation intensity, share of employees involved in R\&D activities, "basicness" of their innovation approach and the share of employees with a university degree is less clear. High values of these measure indicate that the firm has a high absorptive capacity (see Cohen and Levinthal, 1989, 1990), which allows the firm to access a wide range of external knowledge even without co-operating. It also shows that the firm has the

\footnotetext{
${ }^{19}$ The specialized industries will be used as the reference category in the estimations.
} 
ability to generate knowledge it needs for its innovation activities internally, which should decrease the likelihood that it needs to access external knowledge. On the other hand, it may be more likely to co-operate to access critical complementary knowledge, because its own innovation and $R \& D$ activities enlarge its "technological horizon" and open up different uses of its own knowledge that may require additional external knowledge to be turned into products. The empirical findings presented in the literature review propose a positive impact of various measures of absorptive capacity on the probability of co-operating on innovation in general.

The expected effect of the size of a firm is also ambiguous. On the one hand, if larger firms were more diversified than smaller firms then they should be more likely to co-operate on several projects for several different reasons. On the other hand, larger firms have more knowledge and resources inside the firm and are thus less dependent on external contributions.

The use of protection methods indicates that a firm is concerned with protecting the knowledge it generates internally. Whether this leads to more co-operation or less is uncertain. Firms will have to co-operate with each other in order to be able to access and use each others knowledge, but they may also be reluctant to do so, because they are concerned with giving access to their knowledge to external partners. If the latter is the case we should see a negative effect of the importance of protection methods on motives that involve knowledge sharing. The so called "open innovation" paradigm (see Chesbrough, 2003) suggests that firms use patents and other protection methods to disseminate their knowledge and in order to profit from the use of their own knowledge by others. This can be interpreted as suggesting that firms that assign a high importance to formal protection methods are more likely to co-operate on the commercialization of their inventions and innovations.

Public funding for innovation activities has been shown to have a positive influence on the likelihood that a firm co-operates. If it leads firms to co-operate for specific motives is less clear however and is likely to depend on the type of public program the firm is involved in. Since our measure is based on a wide range of public programs we have no particular expectation about this variable per se.

The expected effect of the rest of the variables is easier to determine: We expect firms from industries related to science to co-operate on motives related to knowledge, while labour- and resource-intensive firms should be more likely to co-operate to scale up production and commercialization innovations. We also expect that firms try to overcome obstacles to innovation activities by cooperating. The analysis of cost and risk motives as well as the resource based view (access to complementarities) supports this assumption. Therefore firms that have relatively more problems with obstacles related to commercialization should be more likely to co-operate with external partners to commercialize innovations and vice versa. 
The expected effect of concentration on the demand side is a negative one: concentration should decrease firms' propensity to co-operate for commercialization motives. Firms which serve only a few customers do not need to partner with other firms to adequately serve these customers. They might even just custom make solutions or innovations for their customers.

The export share should have a positive effect on all motives. A high export share is an indication of more intense competition and should lead firms to cooperate, both to develop innovations for foreign markets and to be able to access the foreign markets.

\section{Econometric Model}

The choice of the empirical model to investigate if the expected effects do materialise is not straight forward as some issues have to be addressed.

A first issue concerns the dependent variables: The firms were not asked to provide answers on the motives for each of their individual co-operative arrangements, but to give a general assessment of the importance of the motives for all of them. The answers represent a more general view of co-operation on innovation. It is thus not surprising that some firms ticketed more than one option on the questions of motives, i.e. they had more than one motive for co-operating with external partners. It is also feasible to assume that the decision to co-operate on innovation activities for one motive is not independent of the decision to cooperate for another motive. As a result the dependent variables are not independent of each other. In order to take this into account, we will use a multivariate probit estimation procedure which allows us to model a correlation between the different motives via the error term, instead of four independent probit models.

A second issue is selectivity. Only those firms that were involved in innovation co-operations between 2002 and 2004 were asked to indicate their motives for innovation co-operation. This gives rise to a sample selection problem described by (Heckman, 1976; 1979). The general idea behind Heckman's model is that the standard OLS or probit estimations are biased if the dependent variable which is supposed to be explained is only observed for a specific group of firms in the sample. In our case the motives for co-operation can only be observed if firms actually co-operated between 2002 and 2004. The solution proposed by Heckman is to estimate a two equation model. However, in order to be able to apply his model at least one variable is necessary that only influences the first decision but not the second. In our case this would mean that we would need a variable that only influences the decision to co-operate, but not the motives for co-operating. Obviously such a variable does not exist and the Heckman procedure can not be applied. What is more, even though the question in the questionnaire is structured as if the decision to co-operate and the decision on the motives for co-operation were taken in a sequence and were two distinct decision, i.e. first answer the 
question if you co-operated and conditional on saying yes, they provide information on their motives, this is obviously not the case. ${ }^{20}$

To arrive at consistent estimates anyway we use a set-up similar to Belderbos et al. (2004) and Capron and Cincera (2004) ${ }^{21}$, i.e. we set all the variables on motives to zero for firms that did not co-operate between 2002 and 2004. By applying this procedure we will analyse the decision to co-operate for a specific motive and not the decision to co-operate on innovation for a given motive conditional on having decided to co-operate on innovation (see Capron and Cincera, 2004): 9 for a discussion of these issues). All the independent, explanatory variables are not affected by this procedure as they are available for co-operating and non-cooperating firms.

Finally, the data we use for the analysis is from a random stratified sample and not from a random sample. In order to take this into account, we include the weight (inverse probability of being drawn) of each observation (dweight) in our model.

Our formal model looks like this:

$$
\begin{aligned}
& \text { Coop }^{\text {cost }}=\beta^{\prime}{ }_{1} \mathrm{X}+\varepsilon_{1} \quad \text { with } \quad \text { Coop }^{\text {cost }}=1 \text { if Coop }{ }^{\text {cost }}{ }^{*}>0 \\
& \text { Coop }^{\text {cost }}=0 \text { otherwise } \\
& \operatorname{Coop}^{\text {knowl }}=\beta_{2}^{\prime}{ }_{2}+\varepsilon_{2} \quad \text { with } \quad \text { Coop }^{\text {knowl }}=1 \text { if } \text { Coop }^{\text {knowl * }}>0 \\
& \text { Coop }^{\text {knowl }}=0 \text { otherwise } \\
& \mathrm{Coop}^{\text {prod }}=\beta_{3}{ }_{3} \mathrm{X}+\varepsilon_{3} \quad \text { with } \quad \mathrm{Coop}^{\text {prod }}=1 \text { if } \mathrm{Coop}^{\text {prod }}>0 \\
& \text { Coop }^{\text {prod }}=0 \text { otherwise } \\
& \operatorname{Coop}^{\text {com }}=\beta^{\prime}{ }_{4} \mathrm{X}+\varepsilon_{4} \quad \text { with } \quad \mathrm{Coop}^{\mathrm{com}}=1 \text { if } \mathrm{Coop}^{\mathrm{com} *}>0 \\
& \text { Coop }^{\text {com }}=0 \text { otherwise }
\end{aligned}
$$

where $\mathrm{X}$ is the set of independent variables described above. The specific feature of the multivariat probit model is that the pair-wise correlation of the error terms is not equal to zero:

$$
\operatorname{Cov}\left(\varepsilon_{\mathrm{i}}, \varepsilon_{\mathrm{j}}\right)=\rho_{\mathrm{k}} \quad \text { for all } \mathrm{i} \neq \mathrm{j} \text { and } \mathrm{k}=1, \ldots, 6
$$

\footnotetext{
${ }^{20}$ See Mohnen and Hoareau (2003) for a discussion of a similar issue regarding the co-operation questions in innovation surveys.

${ }^{21}$ Belderbos et al. (2004) and Capron and Cincera (2004) use this method to look at co-operation with different partners. Their survey is set-up similar to the one we use, i.e. the partner is only observed if the firm co-operated. Miotti and Sachwald (2003) restrict their sample to co-operating firms and analyse the decision to co-operate with different partners for this sub-sample without taking selectivity into account. Because Heckman showed that these estimates are biased we decided to employ the method of Belderbos et al. (2004) and Capron and Cincera (2004) in this paper.
} 
This model can be solved by employing a maximum-likelihood procedure. To evaluate the likelihood of a certain outcome, the probability of an observation has to be calculated using a four-variate normal probability density function. This poses some problems: It has been shown that standard numerical calculation techniques cannot be used if the normal density function is of an order higher than two. ${ }^{22}$ A way to solve this problem involves using simulation techniques. One, which is now implemented in many statistical packages, is the so-called "GHK-Simulator (Geweke-Hajivassiliou-Keane-Simulator)" for multivariate normal distributions ${ }^{23}$. For our model estimation we use a command programmed by Antoine Terracol for the STATA statistical software package (mvprobit), which relies on the GHK simulation procedure. ${ }^{24}$

22 See Glasgow (2001) for a discussion of the topic.

${ }^{23}$ Other simulators could also be used. Hajivassiliou et al. (1996) review eleven simulators and find that the GHK is the most reliable method for multivariate normal distributions.

${ }^{24}$ The method is known to be sensitive to the number of observations drawn at each iterative step. We thus tested several different settings $(100,50$ and 5 (default setting) iterations). The results only change as far as the size of the coefficients is concerned. The significance levels and qualitative results stay the same. The model presented in the results section uses 100 . 


\section{Results}

The results of the multivariate probit estimation are presented in Table $3^{25}$. A first result of our analysis is that cost-sharing and accessing external knowledge are chosen as innovation co-operation motives by relatively similar firms and that these firms are quite different from those co-operating to scale up production. Firms collaborating with motives related to commercialization of innovations are in the middle, as they share some features with those co-operating to share costs or get access to knowledge and those firms co-operating to scale up production processes. When interpreting these results one has to keep in mind that innovation co-operation in order to share costs, does not include cost-sharing for production and the like, but only sharing the cost for developing innovations. In that sense cost-sharing motives are related to knowledge sharing motives, as they both concern inputs (finance and knowledge) into the innovation process at the development stage. The two other motives, commercialization and scaling up production processes on the other hand are more closely related to the introduction and diffusion stage of the innovation process, with scaling up being between development and diffusion. Firms collaborating in order to commercialize products share some features with those scaling up production. They also share some characteristics with firms co-operating for the other two motives, which is an indication that our assumption that commercialization motives are not only related to current innovation projects but include innovations that were developed before the reference period could be correct. Firms collaborating on the commercialization of products might actually be doing both developing new innovations and commercializing existing (older) ones.

\footnotetext{
${ }^{25}$ All Rhos are significant in the multivariate estimation, indicating that the decision to co-operate for one motive is not taken independently from the decision to co-operate for another motive.
} 
Table 3 Coefficients of the Multivariat Probit Estimation (weighted)

\begin{tabular}{|c|c|c|c|c|c|}
\hline & & $\begin{array}{c}\text { Motive: } \\
\text { Cost } \\
\text { Sharing }\end{array}$ & $\begin{array}{c}\text { Motive: } \\
\text { Know- } \\
\text { ledge }\end{array}$ & $\begin{array}{l}\text { Motive: } \\
\text { Scaling up } \\
\text { Product. }\end{array}$ & $\begin{array}{c}\text { Motive: } \\
\text { Commerci } \\
\text { alization }\end{array}$ \\
\hline Innovation Intensity & Inno_int & $\begin{array}{c}0.002 \\
(0.007)\end{array}$ & $\begin{array}{l}-0.003 \\
(0.006)\end{array}$ & $\begin{array}{c}-0.013^{\mathrm{zz}} \\
(0.006)\end{array}$ & $\begin{array}{l}0.011 * \\
(0.006)\end{array}$ \\
\hline Innovation Intensity, sqrd & Inno_int2 & $\begin{array}{r}-0.00002 \\
(0.0001)\end{array}$ & $\begin{array}{c}0.0001 \\
(0.0001)\end{array}$ & $\begin{array}{l}0.0002^{\mathrm{zz}} \\
(0.0001)\end{array}$ & $\begin{array}{l}-0.0001 \\
(0.0001)\end{array}$ \\
\hline Share of R\&D employees & $\mathrm{Rdp}$ & $\begin{array}{c}-0.005 * * \\
(0.002)\end{array}$ & $\begin{array}{l}-0.001 \\
(0.002)\end{array}$ & $\begin{array}{l}-0.002 \\
(0.003) \\
\end{array}$ & $\begin{array}{c}-0.001 \\
(0.002) \\
\end{array}$ \\
\hline Internal R\&D Activities & Act_rdintp & $\begin{array}{c}0.459 * * \\
(0.148) \\
\end{array}$ & $\begin{array}{c}0.427 * * \\
(0.118) \\
\end{array}$ & $\begin{array}{l}0.272 * \\
(0.149) \\
\end{array}$ & $\begin{array}{c}0.195 \\
(0.140) \\
\end{array}$ \\
\hline Employees with univ. deg. & Uni & $\begin{array}{c}0.006 * * \\
(0.002)\end{array}$ & $\begin{array}{c}0.002 \\
(0.002)\end{array}$ & $\begin{array}{l}0.0003 \\
(0.003)\end{array}$ & $\begin{array}{l}-0.001 \\
(0.003)\end{array}$ \\
\hline „Basicness“ of inno. act. & Basic & $\begin{array}{c}0.526 * * * \\
(0.096)\end{array}$ & $\begin{array}{c}0.410 * * * \\
(0.095)\end{array}$ & $\begin{array}{c}0.124 \\
(0.109) \\
\end{array}$ & $\begin{array}{l}0.227 * * \\
(0.113)\end{array}$ \\
\hline Strategic protection meth. & Prot_strat & $\begin{array}{c}0.360 * * \\
(0.143)\end{array}$ & $\begin{array}{c}0.209 * * \\
(0.100)\end{array}$ & $\begin{array}{c}0.177 \\
(0.112)\end{array}$ & $\begin{array}{c}0.110 \\
(0.115)\end{array}$ \\
\hline Legal protection methods & Prot_form & $\begin{array}{l}0.225^{*} \\
(0.130)\end{array}$ & $\begin{array}{c}0.396 * * * \\
(0.124)\end{array}$ & $\begin{array}{c}0.370 * * \\
(0.148)\end{array}$ & $\begin{array}{l}0.213^{*} \\
(0.128)\end{array}$ \\
\hline Product first Nor. America & Pdnov_4 & $\begin{array}{l}-0.104 \\
(0.106) \\
\end{array}$ & $\begin{array}{l}-0.045 \\
(0.108)\end{array}$ & $\begin{array}{l}-0.135 \\
(0.146)\end{array}$ & $\begin{array}{c}0.128 \\
(0.119)\end{array}$ \\
\hline Product world first & Pdnov_5 & $\begin{array}{c}0.085 \\
(0.112)\end{array}$ & $\begin{array}{c}0.068 \\
(0.109)\end{array}$ & $\begin{array}{c}-0.078 \\
(0.137)\end{array}$ & $\begin{array}{c}0.133 \\
(0.123)\end{array}$ \\
\hline Process first Nor. America & Pznov_4 & $\begin{array}{c}0.367 * * * \\
(0.140)\end{array}$ & $\begin{array}{c}0.387 * * * \\
(0.141)\end{array}$ & $\begin{array}{c}0.074 \\
(0.174)\end{array}$ & $\begin{array}{c}0.058 \\
(0.157)\end{array}$ \\
\hline Process world first & Pznov_5 & $\begin{array}{c}0.226 \\
(0.156)\end{array}$ & $\begin{array}{c}0.121 \\
(0.151)\end{array}$ & $\begin{array}{c}0.271 \\
(0.191)\end{array}$ & $\begin{array}{c}0.181 \\
(0.192)\end{array}$ \\
\hline Market Introduction Act. & Act_market & $\begin{array}{l}-0.129 \\
(0.149) \\
\end{array}$ & $\begin{array}{c}0.124 \\
(0.098)\end{array}$ & $\begin{array}{c}0.171 \\
(0.117) \\
\end{array}$ & $\begin{array}{c}0.143 \\
(0.118) \\
\end{array}$ \\
\hline Post-intr. Commerc. Act. & Act_com & $\begin{array}{c}0.023 \\
(0.080) \\
\end{array}$ & $\begin{array}{c}0.007 \\
(0.074) \\
\end{array}$ & $\begin{array}{l}0.174 * \\
(0.097)\end{array}$ & $\begin{array}{c}0.119 \\
(0.083) \\
\end{array}$ \\
\hline Obstacles to innovation & Obst_rel & $\begin{array}{l}-0.023 \\
(0.027) \\
\end{array}$ & $\begin{array}{l}-0.008 \\
(0.022)\end{array}$ & $\begin{array}{l}-0.026 \\
(0.024) \\
\end{array}$ & $\begin{array}{l}-0.057 * \\
(0.031)\end{array}$ \\
\hline Public Support for Innov. & Public & $\begin{array}{c}0.097 \\
(0.089) \\
\end{array}$ & $\begin{array}{c}0.154 * * * \\
(0.080)\end{array}$ & $\begin{array}{c}0.043 \\
(0.103) \\
\end{array}$ & $\begin{array}{c}0.133 \\
(0.094) \\
\end{array}$ \\
\hline Size, natural log & Lnemp & $\begin{array}{c}-0.039^{\mathrm{zZz}} \\
(0.228)\end{array}$ & $\begin{array}{c}-0.248^{\mathrm{zz}} \\
(0.222)\end{array}$ & $\begin{array}{c}-0.144 \\
(0.254)\end{array}$ & $\begin{array}{c}0.156 \\
(0.248) \\
\end{array}$ \\
\hline Size, natural log, squared & Lnemp2 & $\begin{array}{c}0.017^{\text {ZZZ }} \\
(0.023)\end{array}$ & $\begin{array}{l}0.035^{\mathrm{zZ}} \\
(0.022)\end{array}$ & $\begin{array}{c}0.022 \\
(0.027)\end{array}$ & $\begin{array}{c}-0.016 \\
(0.026)\end{array}$ \\
\hline
\end{tabular}




\begin{tabular}{|c|c|c|c|c|c|}
\hline Export-Share & Exp_share & $\begin{array}{l}-0.002 * \\
(0.001)\end{array}$ & $\begin{array}{l}-0.002 * \\
(0.001)\end{array}$ & $\begin{array}{l}-0.0001 \\
(0.002)\end{array}$ & $\begin{array}{c}-0.001 \\
(0.001)\end{array}$ \\
\hline Demand-side concentra. & Demand & $\begin{array}{c}0.003 \\
(0.002)\end{array}$ & $\begin{array}{c}0.002 \\
(0.001)\end{array}$ & $\begin{array}{l}0.003 * \\
(0.002)\end{array}$ & $\begin{array}{l}-0.0001 \\
(0.002)\end{array}$ \\
\hline Part of a group of firms & Group & $\begin{array}{c}0.121 \\
(0.089)\end{array}$ & $\begin{array}{c}0.101 \\
(0.081)\end{array}$ & $\begin{array}{c}0.124 \\
(0.107)\end{array}$ & $\begin{array}{c}-0.034 \\
(0.091)\end{array}$ \\
\hline Resource-intensive ind. & Ress-int & $\begin{array}{l}-0.041 \\
(0.121) \\
\end{array}$ & $\begin{array}{c}0.111 \\
(0.122) \\
\end{array}$ & $\begin{array}{c}0.134 \\
(0.179) \\
\end{array}$ & $\begin{array}{l}0.249 * \\
(0.149)\end{array}$ \\
\hline Labour-intensive industry & Labour-int & $\begin{array}{c}0.077 \\
(0.125) \\
\end{array}$ & $\begin{array}{c}0.064 \\
(0.119) \\
\end{array}$ & $\begin{array}{l}-0.045 \\
(0.154) \\
\end{array}$ & $\begin{array}{c}0.175 \\
(0.141) \\
\end{array}$ \\
\hline Scale-intensive industry & Scale-int & $\begin{array}{c}0.067 \\
(0.123) \\
\end{array}$ & $\begin{array}{c}0.118 \\
(0.117) \\
\end{array}$ & $\begin{array}{c}0.232 \\
(0.155) \\
\end{array}$ & $\begin{array}{c}0.311 * * \\
(0.141)\end{array}$ \\
\hline Scientific industry & Science & $\begin{array}{c}0.346^{* * *} \\
(0.134)\end{array}$ & $\begin{array}{c}0.339 * * * \\
(0.127)\end{array}$ & $\begin{array}{c}-0.086 \\
(0.159) \\
\end{array}$ & $\begin{array}{c}0.406 * * * \\
(0.140)\end{array}$ \\
\hline Constant & & $\begin{array}{c}-2.35 * * * \\
(0.557)\end{array}$ & $\begin{array}{c}-1.63 * * * \\
(0.551)\end{array}$ & $\begin{array}{c}-1.976^{* *} \\
(0.625)\end{array}$ & $\begin{array}{c}-2.51 * * * \\
(0.605)\end{array}$ \\
\hline $\begin{array}{l}\text { Observations } \\
\mathrm{X}^{\wedge} 2 \\
\text { Log-likelihood }\end{array}$ & & Unweigh & $\begin{array}{r}\text { ed : 4,021 } \\
43 \\
-10,4\end{array}$ & $\begin{array}{l}\text { Weighted: } \\
.73 \\
9.351\end{array}$ & 0,860 \\
\hline Rhos & & $\begin{array}{l}(1,2) \\
(1,3) \\
(1,4)\end{array}$ & $\begin{array}{l}0.887 * * * \\
0.746 * * * \\
0.803 * * *\end{array}$ & $\begin{array}{l}(2,3) \\
(2,4) \\
(3,4) \\
\end{array}$ & $\begin{array}{l}0.864 * * * \\
0.849 * * * \\
0.792 * * *\end{array}$ \\
\hline
\end{tabular}

$* 10 \%, * * 5 \%, * * * 1 \% \quad$ Significance-level

z 10\%, zz 5\%, zzz 1\% Joint significance-level

Robust Standard Errors in parenthesis

Observations are weighted with the inverse of the probability to be sampled

Source: Statistics Canada, Survey of Innovation 2005, author's calculations

Another general result of our analysis is that factors representing the innovation behaviour as well as variables representing framework conditions and firm characteristics do influence the choice of co-operation motive at least to a certain degree. We find relatively the most significant results for a firm's innovation strategy in terms of their research approach and the use of protection methods. This indicates that the co-operation behaviour is embedded in the overall innovation strategy of firms.

It also supports other studies that find that firms which are concerned with the protection of their inventions and innovations from spilling over to competitors are more likely to co-operate than other firms. Firms that protect knowledge and inventions through patents or trademarks are more likely to co-operate in general than firms that assign only little importance to formal protection methods, as the significance of this variable in all four equations indicates. Patents and trademarks may be a way to signal technological excellence to potential partners 
and thus make firms more likely to co-operate with a firm holding a patent or trademark. ${ }^{26}$ As a result firms which assign a high importance to formal protection methods and want to co-operate may have it easier to find an adequate partner than other firms. For strategic protection methods this effect should not exist. We find however, that firms that assign a high importance to strategic protection methods are more likely to co-operate to share costs and access knowledge than firms which assign these methods less importance. The empirical papers looking at knowledge spillovers and $\mathrm{R} \& \mathrm{D}$ co-operation have found a positive effect of this variable on the likelihood to co-operate as well. They argue that it is an indication that firms try to channel knowledge outflows. What our results show is that the effect works mainly through cost-sharing and access to knowledge motives, without providing further information why this is the case.

Turning to the more detailed results across the different motives, we find a positive and significant effect of internal R\&D activities on the probability to cooperate with external partners in order to share costs, scale up production and access knowledge. The share of employees with a university degree has a significant positive effect on cost-sharing only. The innovation intensity effects the motive scaling up production processes in a U-shaped fashion, i.e. up to an intensity of $32 \%$ the probability to collaborate in order to scale up production decreases and afterwards it increases. ${ }^{27}$ For commercialization motives we find a significant (90\%-level) positive linear influence of innovation intensity. All these findings point to the importance of absorptive capacity for innovation cooperation. As the literature review has shown, many authors find a positive influence of absorptive capacity on the likelihood of co-operating on innovation activities. Our findings add to this literature and show that different measures or components of absorptive capacity influence different motive for co-operation. The share of university graduates in total employment only influences cooperation for reasons of cost-sharing. The negative influence of the innovation intensity in the scaling up production equation up to intensities of $32 \%$ does not necessarily imply that absorptive capacity has a negative influence on cooperation in order to scale up production. This finding may very well be due to the fact that innovators with very low innovation intensities are doing little knowledge intensive activities in-house but rather focus on the adaptation, production and distribution of product innovations developed elsewhere. If the innovation intensity increases these firms seem to shift their focus from adapting innovations to more early stages of the innovation process and thus collaborate less to scale up production processes. Firms with higher innovation intensities seem to do both at the same time. If this scenario is true the innovation intensity

\footnotetext{
${ }^{26}$ See Penin (2005) for a discussion of the role of patents in the collaboration process.

${ }^{27}$ The majority of firms have an innovation intensity of less than $32 \%$, the number of firms with a higher intensity is fairly large, however, and is thus not considered as outlier values.
} 
should be seen as an indicator of the type of innovation activity and not absorptive capacity. ${ }^{28}$

Contrary to our expectation only the novelty of process innovation has a positive influence on some of the innovation motives (cost-sharing and access to knowledge). We would have expected a much more pronounced effect and in particular one related to product innovations, as usually more product than process innovations are jointly developed. What is even more surprising is that it is the first to North-America processes that influence the motives and not the world first processes. A reason for the latter finding could be that world first innovations are developed by firms at the technological frontier, which rely less on input from other firms, because the external knowledge is of little value to them. Firms which introduce new to North-America innovations may also be at the frontier, but seem still to profit from knowledge spillovers and need to combine knowledge held at different locations, as the positive effect on accessing knowledge as a motive for collaboration indicates.

One of the reasons for public funding of collaborative $R \& D$ and innovation activities between firms and public institutions is to increase the flow of knowledge within the national system of innovation. Our results show that public funding policy seems to achieve that goal. The public funding variable has a strong significant positive effect on the likelihood that a firm co-operates to access external knowledge. This means that innovators that receive public funding do significantly more often co-operate in order to get access to external knowledge, than non funded innovators.

The technological environment and general firm characteristics have a very limited influence on the choice of motives. We obtain only marginally significant influences for the export share and demand-side concentration for some motives. Our results provide strong evidence for our expectation however, that firms from industries that are close to science are more likely to co-operate than firms from other industries. Firms from science industries are more likely to co-operate on innovation activities to share costs, access external knowledge and to commercialize product innovations. Being from a scale intensive industry increases the likelihood to collaborate for commercialization motives, which is an effect that is not surprising. Firms relying on large scale production should naturally be interested in expanding their market(s) in order to realize scale economies.

We also find a robust effect of size on the likelihood to co-operate in order to share costs of developing innovations and accessing knowledge. The calculated turning points of the U-shaped influence indicate that there is a non-linear positive effect on cost-sharing (turning point: 3.13 employees) for all the firms in the sample and a non-linear effect on knowledge sharing (turning point: 35

\footnotetext{
${ }^{28}$ See also Schmidt (2005a) who showed that the R\&D intensity does only influence absorptive capacities for university knowledge.
} 
employees). This by and large supports the finding in the literature the larger firms are more likely to co-operate than smaller firms. It looks like the reason why they are more likely to co-operate is that they want to share the costs of developing innovations and access critical complementary knowledge. The calculated turning points indicate that accessing knowledge has a negative effect on firms with less than 35 employees. One possible explanation for this finding is that smaller firms concentrate on their own competencies, capabilities and technological expertise and just need less external information to be successful with their innovation activities. Small firms do join innovation co-operate in order to reduce their costs of developing innovations. Another reason might be that small firms are not able to find a partner that is willing to share its knowledge and expertise with them, because they lack reputation. They might also lack the resources to manage the whole co-operative process and thus opt for less informal ways of collaborating and accessing external knowledge and expertise than the ones we have measured.

\section{Results for Individual Collaboration Motives}

So far we have only looked at the results across (all) motives. Our results are interesting with respect to single motives as well. For sharing the cost of developing innovations we find a negative effect of the share of R\&D employees. This can be explained by the fact that firms with higher in-house R\&D capacities are less dependent on (costly) external resources to develop an innovation. Then again, they should also be less likely to depend on external sources of knowledge and not just external finance. What is more, firms with many internal innovation projects (indicated by a high number of $R \& D$ employees) should incur high innovation costs and be thus more likely to collaborate in order to share costs.

We obtain a negative sign on the coefficient for the share of R\&D employees in the knowledge equation, but it is not significant. It also seems to be an influence specific to R\&D employees, as the share of employees with university degrees, a measure of human capital, has a significant positive influence, so does the "basicness" of their R\&D approach. Other factors that have a significant effect on this motive are strategic and formal protection methods, process first innovations, size, the export share, and belonging to an industry related to science.

As already mentioned above, the factors that influence the likelihood that firms co-operate in order to access knowledge are almost identical to those of the costsharing motive, with the exception of the share of R\&D employees and employees with university degrees (not significant for $m \_k n o w l$ ) and public funding (only significant for $m \_k n o w l$ ).

Only for scaling up production processes as a motive for innovation cooperation significant effects for innovation activities related to post-introduction commercialisation of innovations and demand-side concentration can be found. 
These effects are only significant at the $90 \%$-level, however. The positive influence of both variables is puzzling. Post-introduction commercialisation activities are defined as "activities undertaken to assure the commercial success of your new or significantly improved products" (Statistics Canada, 2005: 6). Given this definition the variable should rather increase the likelihood to cooperate on commercialization, which it does not. The positive effect of a high degree of concentration on the demand side on scaling up production processes is also hard to explain. Our expectation was a negative effect, because more concentrated demand should enable firms to serve its few customers without any external partners.

The last motive we look at is the commercialization motive. Like for the motive "scaling up production processes" we find variables with a significant effect that is unique for this motive: the dummy variable for resource intensive industries, the dummy for scale-intensive industries and obstacles to innovation. The negative sign on the obstacles to innovations, which indicates that firms with fewer problems with respect to commercialisation of innovations are less likely to co-operate for this motive, partially confirms our expectation that firms try to overcome obstacles by co-operating. Then again, we do not find an opposite influence on the development motives, which would support this statement. The industry dummies show that commercialization of innovations is not only relevant for firms closely related to science.

\section{Conclusion}

In this paper we show how firms' characteristics and measures of innovation activities influence their innovation co-operation decision with respect to the underlying motives.

Our findings indicate that firms which co-operate in order to share the costs of developing innovative products and processes and those that join innovation cooperation in order to access external knowledge are quite similar. They have R\&D activities that are relatively more oriented towards basic than applied research, are large in size and more often belong to industries related to science. They also assign a high importance to strategic and formal protection methods. To put it simply, they are more research oriented than other firms. This underscores the importance of knowledge for today's innovation processes.

The firms that co-operate in order to scale up production and to commercialize innovations, respectively, are harder to describe. Both groups have in common, that the innovation intensity has a positive effect after a certain threshold is reached, while the share of employees with university degrees and the share of employees involved in R\&D activities does not. The few significant variables 
may indicate that co-operation for commercialisation and scaling up production processes are motives for innovators in general and not just for a specific group. It may also indicate that factors other than the ones we included here play a role for this type of co-operation motives.

We find some evidence that public funding increases the flow of knowledge within the national system of innovation. Innovators are more likely to cooperate in order to get access to external $R \& D$ and expertise if they receive public funding than if they do not receive public funding. Our analysis also provides some evidence that the innovation co-operation decision is part of the overall innovation strategy of firms.

While our study is an ex-post evaluation of the relationship between cooperation motives and the innovation strategy of firms, future studies could investigate this link in much more detail. Further research may also look at the relationship between co-operation and its motives in areas other than R\&D and innovation. Another more general topic that could be addressed using Canada's Innovation Survey data is the link between the choice of co-operation partner and the underlying motives.

Future research may profit from co-operation between scholars from business administration and economics, with the motive to access each others knowledge. 


\section{Literature}

Abramovsky, L., E. Kremp, A. Lopez, T. Schmidt and H. Simpson (2005), Understanding Co-operative R\&D activity: Evidence from four European countries, IFS Working Paper No. 05/23, London.

Aschhoff, B. and T. Schmidt (2006), Empirical Evidence on the Success of R\&D Cooperation - Happy together?, ZEW Discussion Paper 06-062, Mannheim.

Banerjee, S. and P. Lin (2001), Vertical Research Joint Ventures, International Journal of Industrial Organization 19 (1), 285-302.

Barney, J. (1991), Firm Resources and Sustained Competitive Advantage, Journal of Management 17 (1), 99-120.

Bayona, C., T. Gracia-Marco and E. Huerta (2001), Firms' motivation for cooperative R\&D: An empirical analysis of Spanish firms, Research Policy 30 (8), 12891307.

Belderbos, R., M. Carree, B. Diederen, B. Lokshin and R. Veugelers (2004), Heterogeneity in R\&D Cooperation Strategies, International Journal of Industrial Organization 22 (8-9), 1237-1263.

Bönte, W. and M. Keilbach (2005), Concubinage or Marriage? Informal and Formal Cooperations for Innovation, International Journal of Industrial Organization $23(3-4), 279-302$.

Bordt, M. (2005), Commercialization as a statistical concept?, Innovation Analysis Bulletin 7 (1), 3.

Busom, I. and A. Fernandez-Ribas (2004), Firm Strategies in R\&D: Cooperation and Participation in R\&D Programs, Universida Autonoma de Barcelona Working Paper No. 04.05, Barcelona.

Caloghirou, Y., S. Ioannides and N.S. Vonortas (2003), Research Joint Ventures: A Critical Survey of the Theoretical and Empirical Literature, Journal of Economic Surveys 17 (4), 541-570.

Cantner, U. and A. Meder (2006), Determinants Influencing the Choice of a Cooperation Partner, Jenaer Schriften zur Wirtschaftswissenschaft No. 20/2006, Jena.

Capron, H. and M. Cincera (2004), Industry-University S\&T Transfer: What can we Learn From Belgium CIS-2 Data?, CEPR Discussion Paper Series No. 4685, London. 
Cassiman, B. and R. Veugelers (2002), R\&D Cooperation and Spillovers: Some Empirical Evidence from Belgium, American Economic Review 44 (3), 11691184.

Chesbrough, H.W. (2003), Open Innovation - The New Imperative for Creating and Profiting from Technology, Harvard Business School Press, Boston, USA.

Cincera, M., L. Kempen, B. von Pottelsberghe, R. Veugelers and C. Villegas (2003), Productivity Growth, R\&D and the Role of International Collaborative Agreements: Some Evidence from Belgium Manufacturing Companies, Brussels Economic Review 46 (3), 107-140.

Cohen, W.M. and D.A. Levinthal (1989), Innovation and Learning: The Two Faces of R\&D, Economic Journal 99 (397), 569-596.

Cohen, W.M. and D.A. Levinthal (1990), Absorptive Capacity: A New Perspective on Learning and Innovation, Administrative Science Quarterly 35 (1), 128-152.

D'Aspremont, C. and A. Jacquemin (1988), Cooperative and Noncooperative R\&D in Duopoly with Spillovers, American Economic Review 78 (5), 1133-1137.

Dachs, B., B. Ebersberger and A. Pyka (2004), Why do Firms Co-operate for Innovation? A Comparison of Austrian and Finnish CIS 3 Results, Volkswirtschaftliche Diskussionsreihe der Uni Augsburg No. 255, Augsburg.

De Bondt, R. and R. Veugelers (1991), Strategic Investment with Spillovers, European Journal of Political Economy 7 (7), 345-366.

Dodgson, M. (1994), Technological Collaboration and Innovation, in: Dodgson, M. and R. Rothwell (eds.), The Handbook of Industrial Innovation, Edward Elgar, Cheltenham, 285-292.

European Commission (2004), Innovation in Europe - Results for the EU, Iceland and Norway (Data 1998-2001), Theme 9 Science and Technology, Luxemburg.

Fontana, R., A. Geuna and M. Matt (2005), Factors Affecting University-Industry R\&D Collaboration: The Importance of Screening and Signalling, Document de travail No. 2005-07, Strassburg.

Fritsch, M. and R. Lukas (2001), Who Cooperates on R\&D?, Research Policy 30 (2), 297-312.

Gerybadze, A. (2004), Management von Kooperationen, in: Barske, H., A. Gerybadze, L. Hünninghausen and T. Sommerlatte (eds.), Digitale Fachbibliothek "Innovationsmanagement", Symposium Publishing GmbH, Düsseldorf.

Glasgow, G. (2001), Mixed Logit Models for Multiparty Elections, Political Analysis 9 (2), 116-136. 
Hagedoorn, J. (1993), Understanding the Rationale of Strategic Technology Partnering: Interorganizational Modes of Cooperation and Sectoral Differences, Strategic Management Journal 14 (5), 371-385.

Hagedoorn, J. (2002), Inter-firm R\&D Partnership: An Overview of Major Trends and Patterns since 1960, Research Policy 31 (4), 477-492.

Hagedoorn, J., A.N. Link and N.S. Vonortas (2000), Research Partnerships, Research Policy 29 (4-5), 567-586.

Hajivassiliou, V.A., D.L. McFadden and P. Ruud (1996), Simulation of Multivariate Normal Rectangle Probabilities and Their Derivatives: Theoretical and Computational Results, Journal of Econometrics 72 (1-2), 85-134.

Heckman, J.J. (1976), The Common Structure of Statistical Models of Truncation, Sample Selection and Limited Dependent Variables and a Simple Estimator for Such Models, Annals of Economic and Social Measurement 5, 475-492.

Heckman, J.J. (1979), Sample Selection Bias as a Specification Error, Econometrica 47, 153-161.

Kaiser, U. (2002), An Empirical Test of Models Explaining Research Expenditures and Research Cooperation: Evidence for the German Service Sector, International Journal of Industrial Organization 20 (6), 747-774.

Kaiser, U. and G. Licht (1998), R\&D Cooperation and R\&D Intensity: Theory and Micro-Econometric Evidence for German Manufacturing Industries, ZEW Discussion Paper No. 98-32, Mannheim.

Kamien, M.I., E. Muller and I. Zang (1992), Research Joint Ventures and R\&D Cartels, American Economic Review 82 (5), 1293-1306.

Kogut, B. (1988), Joint Ventures: Theoretical and Empirical Perspectives, Strategic Management Journal 9 (4), 319-332.

Link, A.N. and L.L. Bauer (1987), An Economic Analysis of Co-operative Research, Technovation 6, 247-260.

Miotti, L. and F. Sachwald (2003), Cooperative R\&D: Why and with Whom? An Integrated Framework Analysis, Research Policy 32 (8), 1481-1499.

Mohnen, P. and C. Hoareau (2003), What Type of Enterprises Forges Close Links with Universities and Government Labs? Evidence from CIS-2 Data, Managerial \& Decision Economics 24 (2-3), 133-145. 
Mowery, D., J.E. Oxley and B.S. Silverman (1998), Technological Overlap and Interfirm Cooperation: Implications for the Resource-Based View of the Firm, Research Policy 27 (5), 507-523.

Negassi, S. (2004), R\&D co-operation and innovation a microeconometric study on French firms, Research Policy 33 (3), 365-384.

OECD (1986), Technological Cooperation Agreements between Firms: Some Initial Data and Analysis, Paris.

OECD and Eurostat (1997), Oslo Manual - Proposed Guidelines for Collecting and Interpreting Technological Innovation Data - 2nd Edition, Paris.

Penin, J. (2005), Patents versus ex post rewards: A new look, Research Policy 34, 641656.

Polanyi, M. (1967), The tacit dimension, Doubleday \& Co., Garden City, NY.

Richardson, G.B. (1972), The Organisation of Industry, The Economic Journal 82 (327), 883-896.

Rocha, F. (1999), Inter-firm technological Cooperation: Effects of absorptive capacity, firm-size and specialization, Economics of Innovation \& New Technology 8 (3), 253-271.

Röller, L.-H., M.M. Tombak and R. Siebert (1997), Why firms form Research Joint Ventures: theory and evidence, CEPR Discussion paper Series No. 1654

Sakakibara, M. (1997), Heterogeneity of Firm Capabilities and Cooperative Research and Development: An Empirical Examination of Motives, Strategic Management Journal 18 (6), 143-165.

Schmidt, T. (2005a), Absorptive Capacity - One Size Fits All? A Firm-level Analysis of Absorptive Capacity for Different Kinds of Knowledge, ZEW Discussion Paper No. 05-72, Mannheim.

Schmidt, T. (2005b), Knowledge Flows and R\&D Co-operation: Firm-Level Evidence from Germany, ZEW Discussion Paper No. 5-22, Mannheim.

Statistics Canada (2005), Canadian Survey of Innovation 2005, -Questionnaire, http://www.statcan.ca/english/sdds/instrument/4218_Q1_V5_E.pdf, Downloaded: Oct $15^{\text {th }}, 2006$.

Teece, D.J. (1986), Profiting from Technological Innovation: Implications for Integration, Collaboration, Licensing and Public Policy, Research Policy 15 (6), 285-305. 
Tether, B. (2002), Who Co-operates for Innovation, and Why: An Empirical Analysis, Research Policy 31 (6), 947-967.

The Gazette (2006), Yahoo! eBay link up for online showdown, The Gazette, B6, Issue: May 26, 2006.

Tsang, E.W.K. (2000), Transaction Cost and Resource-based Explanations of Joint Ventures: A Comparison and Synthesis, Organizational Studies 21 (1), 215-242.

Veugelers, R. and B. Cassiman (2005), R\&D Cooperation between Firms and Universities. Some Empirical Evidence from Belgian Manufacturing, International Journal of Industrial Organization 23 (5/6), 355-379.

Wall Street Journal Europe (2006), Ebay talks to Microsoft, Yahoo about foe, Wall Street Journal Europe, 5, Issue: April 24, 2006.

Wernerfelt, B. (1984), A Resource-Based View of the Firm, Strategic Management Journal 5 (2), 171-180. 


\section{Appendix}

Table 4 Construction of the Variables

\begin{tabular}{|c|c|c|}
\hline Variable & Type & Construction \\
\hline Act_rdintp & Dummy & $\begin{array}{l}\text { One, if the firm conducted in-house R\&D between } 2002 \\
\text { and } 2004 \text {. }\end{array}$ \\
\hline Act_market & Dummy & $\begin{array}{l}\text { One, if the firm had activities related to the market } \\
\text { introduction of innovations between } 2002 \text { and } 2004 \text {. }\end{array}$ \\
\hline Act_com & Dummy & $\begin{array}{l}\text { One, if the firm had activities related to post- } \\
\text { introduction commercialization activities for product } \\
\text { innovations between } 2002 \text { and } 2004 \text {. }\end{array}$ \\
\hline Basic & Index & $\begin{array}{l}\text { Average importance of suppliers, clients, customers, } \\
\text { competitors, consultants and commercial labs as } \\
\text { sources of information for innovation divided by the } \\
\text { average importance of universities or other higher } \\
\text { education institutions, colleges or technological } \\
\text { institutes, federal or provincial/territorial R\&D } \\
\text { laboratories and private non-profit R\&D laboratories } \\
\text { (Reference Period 2002-2004). }\end{array}$ \\
\hline Uni & Share & $\begin{array}{l}\text { Share of a firm's full-time employees which have a } \\
\text { university degree in } 2004 \text {. }\end{array}$ \\
\hline Demand & Share & $\begin{array}{l}\text { Share of total revenue in } 2004 \text { that came from the firm's } \\
\text { most important customer or client (outside its group). }\end{array}$ \\
\hline Exp_share & Share & $\begin{array}{l}\text { Share of firm's total revenue from sales of products } \\
\text { (good or services) to clients outside of Canada in } 2004 \text {. }\end{array}$ \\
\hline Group & Dummy & One, if the firm belongs to a group of firms. \\
\hline Inno_int & Share & $\begin{array}{l}\text { Share of a firm's total expenditure that was devoted to } \\
\text { innovation activities in } 2004 \text {. Also included as squared } \\
\text { term (inno_int2). }\end{array}$ \\
\hline Lnemp & $\log$ & $\begin{array}{l}\text { Natural logarithm of the number of employees of a firm } \\
\text { in 2004. Also included as squared term (lnemp2). }\end{array}$ \\
\hline M_cost & Dummy & $\begin{array}{l}\text { One, if a firm's motive for co-operation on innovation } \\
\text { activities between } 2002 \text { and } 2004 \text { was "sharing the cost } \\
\text { of developing innovations". }\end{array}$ \\
\hline M_knowl & Dummy & $\begin{array}{l}\text { One, if a firm's motive for co-operation on innovation } \\
\text { activities between } 2002 \text { and } 2004 \text { was "Accessing } \\
\text { R\&D” and/or "Accessing critical expertise". }\end{array}$ \\
\hline M_prod & Dummy & $\begin{array}{l}\text { One, if a firm's motive for co-operation on innovation } \\
\text { activities between } 2002 \text { and } 2004 \text { was "Scaling up } \\
\text { production processes". }\end{array}$ \\
\hline M_com & Dummy & $\begin{array}{l}\text { One, if a firm's motive for co-operation on innovation } \\
\text { activities between } 2002 \text { and } 2004 \text { was "Accessing new } \\
\text { markets" and/or "Accessing new distribution channels". }\end{array}$ \\
\hline Obst_dev & Index & $\begin{array}{l}\text { Sum of importance (between } 0 \text { (not used) and } 3 \text { (high)) } \\
\text { of the following obstacles to innovation activities: lack } \\
\text { of funds within a firm, lack of finance from sources }\end{array}$ \\
\hline
\end{tabular}




\begin{tabular}{|c|c|c|}
\hline & & $\begin{array}{l}\text { outside a firm, innovation costs too high, lack of } \\
\text { qualified personnel, lack of information on technology, } \\
\text { difficulty in finding cooperation partner, inability to } \\
\text { devote staff to innovation projects and risk related to } \\
\text { the feasibility of the innovation project. Rescaled } \\
\text { between } 0 \text { (not used) and } 1 \text { (highly important). } \\
\text { (Reference Period 2002-2004) }\end{array}$ \\
\hline Obst_com & Index & $\begin{array}{l}\text { Sum of importance (between } 0 \text { (not used) and } 3 \text { (high)) } \\
\text { of the following obstacles to innovation activities: } \\
\text { market dominated by established firm, uncertain } \\
\text { demand for innovations, lack of knowledge on markets, } \\
\text { insufficient marketing effort, inappropriate targeting, } \\
\text { inappropriate packaging, lack of consumer acceptance, } \\
\text { lack of standards and regulations. Rescaled between } 0 \\
\text { (not used) and } 1 \text { (highly important). (Reference Period } \\
\text { 2002-2004) }\end{array}$ \\
\hline Obst_rel & Index & $\begin{array}{l}\text { Relative importance of obstacles to the development of } \\
\text { innovations between } 2002 \text { and 2004, i.e. obst_dev } \\
\text { divided by obst_com. }\end{array}$ \\
\hline Pdnov_4 & Dummy & $\begin{array}{l}\text { One, if a firm introduced only product innovations } \\
\text { between } 2002 \text { and } 2004 \text { that were either new to their } \\
\text { province/territory, new to Canada or new to North } \\
\text { America, but not new to the world. }\end{array}$ \\
\hline Pdnov_5 & Dummy & $\begin{array}{l}\text { One, if a firm introduced product innovations between } \\
2002 \text { and } 2004 \text { that were new to the world }\end{array}$ \\
\hline $\begin{array}{l}\text { Pznov_4- } \\
\text { Pznov_5 }\end{array}$ & Dummy & Analogous to Pdnov_4 and Pdnov_5 \\
\hline Prot_strat & Index & $\begin{array}{l}\text { Sum of importance (between } 0 \text { (not used) and } 3 \text { (high)) } \\
\text { of strategic protection methods for innovations } \\
\text { (secrecy, complexity of design, lead-time advantage). } \\
\text { Rescaled between } 0 \text { (not used) and } 1 \text { (highly important). } \\
\text { Reference period } 2002-2004 \text {. }\end{array}$ \\
\hline Prot_form & Index & $\begin{array}{l}\text { Sum of importance (between } 0 \text { (not used) and } 3 \text { (high)) } \\
\text { of formal protection methods for innovations (patents, } \\
\text { trademarks). Rescaled between } 0 \text { (not used) and } 1 \\
\text { (highly important). Reference period 2002-2004. }\end{array}$ \\
\hline Public & Dummy & $\begin{array}{l}\text { One, if the firm used any of the following programs } \\
\text { sponsored by the federal or provincial/territorial } \\
\text { government program for innovation activities between } \\
2002 \text { and 2004: R\&D tax credits, government R\&D } \\
\text { grants, government venture capital support or } \\
\text { government technological support and assistance } \\
\text { programs. }\end{array}$ \\
\hline Rdp & Share & $\begin{array}{l}\text { Share of firm's full-time employees who were involved } \\
\text { in R\&D activities in } 2004 \text {. }\end{array}$ \\
\hline Dweight & Weight & Weight of each firm in the sample. \\
\hline
\end{tabular}


Table 5 Construction of the Industry Variables

\begin{tabular}{|l|l|l|}
\hline Industries & & \\
\hline $\begin{array}{l}\text { Resource } \\
\text { intensive }\end{array}$ & Dummy & $\begin{array}{l}\text { One, if a firm belongs to a resource-intensive industry } \\
\text { (NAICS 113, 311, 312, 321, 322, 324, 327) }\end{array}$ \\
\hline $\begin{array}{l}\text { Labour } \\
\text { intensive }\end{array}$ & Dummy & $\begin{array}{l}\text { One, if a firm belongs to a labour-intensive industry } \\
\text { (NAICS 313, 314, 315, 316, 332, 337, 339) }\end{array}$ \\
\hline $\begin{array}{l}\text { Scale } \\
\text { intensive }\end{array}$ & Dummy & $\begin{array}{l}\text { One, if a firm belongs to a scale-intensive industry } \\
\text { (NAICS 323, 325 excl. 3254, 326, 331, 336 excl. 3364) }\end{array}$ \\
\hline Science & Dummy & $\begin{array}{l}\text { One, if a firm belongs to an industry based on science } \\
\text { (NAICS 3254, 3341, 3342, 3343, 3344, 3345, 3346, } \\
\text { 3364) }\end{array}$ \\
\hline Specialized & Dummy & $\begin{array}{l}\text { One, if a firm belongs to a specialized industry (NAICS } \\
\text { 333 excl. 3341-3346, 335) }\end{array}$ \\
\hline
\end{tabular}

